\title{
Evaluation of Fungi Isolated in the Veterinary Microbiology Laboratory in Terms of Human Health
}

\author{
S. Kahya Demirbilek, Ö. Ardıçlı, H. Kurnaz
}

10.18805/IJAR.B-1374

\begin{abstract}
Background: The importance of zoonotic fungal infections is increasing today and continues to increase due to changing living conditions.

Methods: Between 2012 and 2019 evaluated of fungi species isolated from 51 (20.07\%) of 254 samples from 10 different animal species (dog, cat, horse, cow, goat, sheep, camel, penguin, bird, rabbit) with 10 different sample types Thus, the risk of those with zoonotic characteristics was assessed. Despite fungal hyphae and/or spores were seen in $63(24.8 \%)$ of 254 samples in the direct microscopic examination, the isolation of fungi on Sabouraud dextrose agar occurred in only 51 of these samples (20.07\%).

Conclusion: Of all the 51 samples, $9(17.64 \%)$ samples had more than one fungal agent. The predominant isolate was Aspergillus spp. with an isolation rate of 24 (47.05\%), followed by Malassezia spp. 11 (21.56\%), Alternaria spp. 6 (11.76\%), Penicillium spp. and various yeasts 4 (7.84\%), Microsporum spp. 3 (5.88\%), Candida spp., Mucor spp., Geotrichum spp. 2 (3.92\%) and Trichophyton spp. and Rhizopus spp. 1 (1.96\%). Besides, samples were examined for the presence of bacteria and one or more of the bacteria were also isolated from $14(27.4 \%)$ of 51 samples. This assessment in the veterinary microbiology laboratory has shown that the isolated fungi agents pose a significant risk of infection for people who take care of these animals or consume animal products and pet owners.
\end{abstract}

Key words: Animal, Dermatophytosis, Fungal infection, Human, Zoonosis.

\section{INTRODUCTION}

In veterinary medicine, fungal infections have often been reported in recent years (Ditrich et al. 1990; Mantovani and Monganti et al. 1977; Gerçeker et al. 2004; Cafarchia et al. 2004). Although there are studies on fungal infections, many aspects of these infections are still not fully understood. For example, there are still uncertainties about the role of animals in fungal infections in humans such as which animals are the vector of which fungal infection or which animal is the reservoir or host Jose and Matra (2010).

The prognosis of the infection varies significantly depending on the type of agent and the susceptibility of the host. It is reported that an average of $10-20 \%$ of people are at risk of dermatomycosis throughout their lives (Gürcan et al. 2008). It has been reported that almost $80 \%$ of human dermotophytosis infections in rural areas are of animal origin, and in urban areas, approximately $20 \%$ of these infections are transmitted from pets. As molecular methods for the diagnosis of fungal infections are developed, it may become apparent that many fungal infections that are now sporadically seen in the next few years are actually more common. It is expected that the group accepted as zoonotic in fungal infections will expand further with the development of molecular techniques and epidemiological studies developed in the coming years (Jose et al. 2010; Hailu 2018).

Mycotoxins are the second fungal metabolites produced by molds and pose a significant health risk to humans and animals, other than their toxic effects. They have also mutagenic, carcinogenic, teratogenic, hallucinogenic, estrogenic, tremorgenic effects. Basic mycotoxin for milk
Uludag University, Faculty of Veterinary Medicine, Department of Microbiology, 16.000, Görükle-Bursa, Turkey.

Corresponding Author: S. Kahya Demirbilek, Uludag University, Faculty of Veterinary Medicine, Department of Microbiology, 16.000, Görükle-Bursa, Turkey. Email: serpilkahya@uludag.edu.tr

How to cite this article: Demirbilek, S.K., Ardiçlı, Ö., Kurnaz, H. (2021). Evaluation of Fungi Isolated in the Veterinary Microbiology Laboratory in terms of Human Health Indian Journal of Animal Research. DOI: 10.18805/IJAR.B-1374.

Submitted: 15-04-2021 Accepted: 15-06-2021 Online: 30-07-2021

and dairy products Aspergillus spp. and especially aflatoxin M1 has a carcinogenic effect (Kırdar et al. 2006).

This study was thought to make a significant contribution to the literature in today's conditions where dermatophytosis, especially zoophilic ones, contact with pets in milk, which is the most consumed product among animal products and in samples of animal origin with suspected fungal infections. This study aimed to guide physicians in the diagnosis.

\section{MATERIALS AND METHOdS Sample Collection}

Two hundred and fifty four samples used in the study, 10 different sample types (skin scraping, nasal swab, eye swab, nipple swab, dental swab, abscess contents, joint fluid, milk, lung) taken from 10 different animal (dog, cat, horse, cow, goat, sheep, camel, penguin, bird, rabbit) species that came 
to our laboratory between 2012-2019 with findings of fungal infection. The samples were examined both from a mycological and bacteriological point of view. The isolated bacteria were identified on the basis of cultural, morphological, and biochemical characteristics (Quinn et al. 1999). None of the animals to be sampled were treated for any fungal or bacterial infection before the sample was taken. All samples were studied in Uludag University Faculty of Veterinary Medicine Microbiology Department.

\section{Direct microscopic examination}

A small amount of sample was taken on the slide and treated with $15 \% \mathrm{KOH}$ solution. A coverslip was covered over this mixture, heated very slightly from the bottom and left at room temperature for about 20 minutes. Spore, conidia and hypha structures were examined with $20 \mathrm{X}$ and then $40 \mathrm{X}$ lenses of the microscope.

\section{Fungal isolation}

Fungal isolation and identification of all clinical specimens were performed in accordance with standard microbiological methods (CLSI, 2012).

\section{Bacteria isolation and identification}

For bacteriological examination, 254 samples that came with suspicion of fungal infection were inoculated on $5 \%$ sheep blood agar, Eosine-methylene blue agar and MacConcey agar. Media were incubated in an aerobic environment at $37^{\circ} \mathrm{C}$ for $24-48$ hours. Bacteria were identified on the basis of colonial characteristics on different media, gram staining, hemolytic properties and different biochemical tests.

\section{RESULTS AND DISCUSSION}

Diseases that are transmissible among humans, wild, and domestic animal species have a significant impact on the protection of public health, livestock economy and wildlife. According to Cleaveland et al. (2001) approximately $61 \%$ of human infections are zoonotic, with 499 (26\%) of 1922 infectious agents causing fungal infections. The frequency and number of fungal infections are increasing, and changes are observed in the fungi that cause the infection over time. Recently, Gülmez et al. (2021) examined the samples that had been submitted to the hospital mycology laboratory in the preceding 12 years and made fungal isolation from 21813 of 19636 clinical samples. The authors found a 2.5fold increase in fungal infections between the first and the subsequent six years, while also noting a significant increase in mold isolation rate in the second six-month period in all samples.

The most frequently isolated yeast was Candida albicans (57\%), followed by mold fungus Aspergillus spp. $(47.05 \%)$. Most importantly, the authors reported that the sensitivity of fungi isolated from clinical specimens to antifungal drugs decreased significantly over the 12-year study period. Due to the slow reproduction of fungi, it takes a long time to determine the agent and its species and to perform antifungal susceptibility tests. Although studies on fungal infections are rare, authors of more recent investigations have not only isolated fungi known to reproduce extensively, but have also isolated different types of fungi. For example, Alternaria alternate with zoonotic importance have been detected in dogs for the first time in a case study conducted in Turkey (Avsever et al. 2017), whereas our investigation uncovered six Alternaria spp., equivalent to $11.76 \%$ of the analyzed samples. These findings further highlight the importance of having access to accurate epidemiological data for determining initial treatments for fungal infections (Gülmez et al. 2021). Considering that almost $61 \%$ of human infections are zoonoses, it is imperative to jointly evaluate data obtained from both human and animal laboratories.

Due to the increase in the life expectancy and the growing reliance on antibiotics and cytotoxic drugs, as well as longer lifespan for people suffering from chronic diseases and those who have undergone chemotherapy, infections with fungi such as Trichosporon, Fusarium and Geotrichum are on the rise. These species were previously considered to be contaminants that do not cause significant morbidity and mortality in people with weakened immune systems (Demir and KuŞtimur 2014). In our study, a significant amount of fungi was also isolated from cow's milk (Table 1). Mycotoxins with toxic properties are mainly produced by fungi belonging to the species Aspergillus, Penicillium, Fusarium, Rhizopus, Alternaria and Clavipes. Studies on samples taken from meat, eggs, milk and various organs of poultry, ovine and bovine animals show that even low consumption of mycotoxins can affect various animal tissues and products, especially liver, eggs and milk. Different amounts of aflatoxin were detected in 51 (85\%) of 60 raw milk samples as well as in $37(61.7 \%)$ of 60 pasteurized milk samples examined by Diler (2019). Aspergillus spp. toxigenic fungal infections can also be detected in domestic pets (Boynukara et al. 2019; Gülmez et al. 2021).

When fungal infections in animals do not affect physiological functions, they are typically not treated, thus increasing the potential for human contamination (Mantovani and Monganti 1977; Ditrich et al. 1990). As infective fungal spores can be spread by pets such as cats and dogs, they can easily cause infection in humans (Gerçeker et al. 2004). For example, Microsporum canis (M. canis) often causes infections in people who come into contact with cats and dogs. Several authors have, however, argued that zoophilic dermatophytes are more common in young individuals than anthropophilic dermatophytes (Mantovani and Monganti 1977; Ditrich et al. 1990). In the anamnesis of the 27-yearold woman who applied to the healthcare facility with an itchy and circular lesion, it was revealed that her cat, with whom she lived for two weeks, had hair loss in the ear (Mýsýr et al. 2019). In contrast, Gürcan et al. (2008) failed to find any link between the risk of dermotophytosis and having dogs and cats as pets, calling for additional studies with more patients to resolve this discrepancy. More recently, in their study on 362 clinically dermatophyte suspicious 


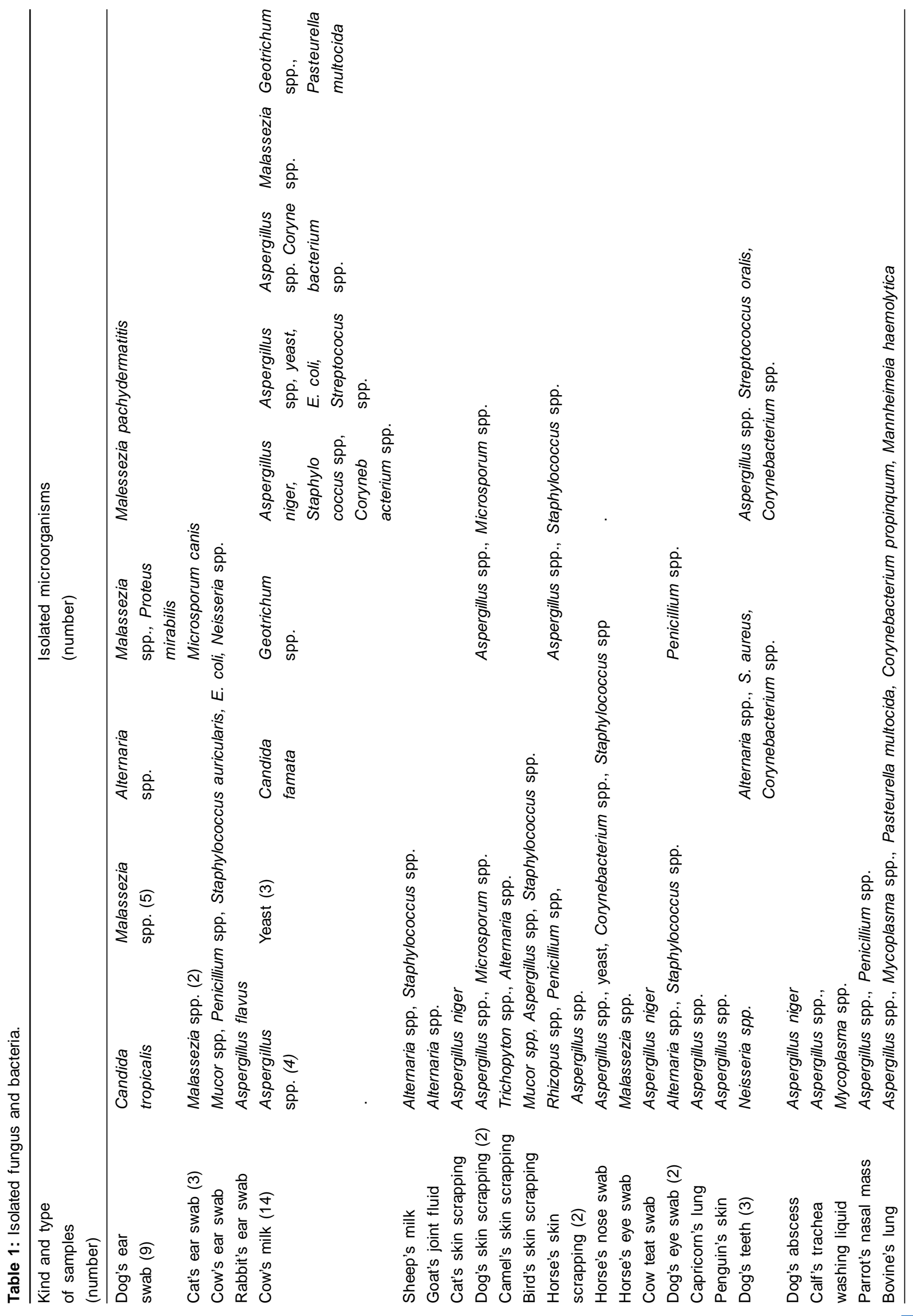


samples taken from cats, dogs and their owners, Murmu et al. (2017) found 285 (78.7\%) positive samples, $55.4 \%$ of which belonged to cats, $37.9 \%$ to dogs, and $6.7 \%$ to their owners. They primarily isolated $M$. canis $(60 \%)$, followed by M. gypseum (22.5\%), T. mentagrophytes (15.8\%) and T. rubrum $(1.7 \%)$. In their study, Haggag et al. (2017) examined 50 cows, 25 buffaloes, 50 sheep and 25 horses for the presence of dermatophytes, and performed an average of $74 \%$ dermatophyte isolations. Their findings revealed that $T$. verrucosum was most prevalent $(47.33 \%)$, followed by $T$. mentagrophytes. In addition, $82 \%$ (52\% males and $30 \%$ females) of the clinically suspected human samples were found to be positive.

In our study, fungi were isolated in SDA from 51 $(20.07 \%)$ of 254 samples. In addition, more than one fungal agent was isolated from nine (17.64\%) of these samples. The most frequently isolated fungi were Aspergillus spp. (24, $47.05 \%)$, followed by Malassezia spp. (11, 21.56\%), Alternaria spp. (6, 11.76\%), Penicillium spp. and various yeasts (4 each, 7.84\%), Microsporum spp. (3, 5.88\%), Candida spp., Mucor spp., Geotrichum spp. (2 each, 3.92\%) and Trichophyton spp. and Rhizopus spp. (1 each, 1.96\%), as shown in Table 1. Fungal infections in animals have been extensively studied (Mantovani and Monganti 1977; Cafarchia et al. 2004; Yahyaraeyat et al. 2009; Murmu et al. 2017; Hailu et al. 2018). Yahyaraeyat et al. (2009) examined 487 samples from different animals (292 dogs, 124 cats, 28 cows, 15 sheep, 11 chickens, 6 goats, 5 horses, 5 rabbits and 1 fox) for dermatophytosis over a 4-year period. They most frequently isolated $M$. canis $(53.5 \%)$, followed by $T$. mentagrophytes $(20.2 \%), T$. verrucosum $(17.5 \%)$ and $M$. gallinea, highlighting the importance of periodic check-ups in animals for public health.

DM examination is a fast and sensitive diagnostic method that is widely used in fungal infections. Sometimes fungal elements can be seen in DM, but reproduction does not occur in their cultures or vice versa. Therefore, both DM and culture should be used in the diagnosis of mycosis. Although fungal hyphae and/or spores were observed in 63 (24.8\%) of 254 samples examined as DM in our study, only $51(20.07 \%)$ of these samples were isolated in SDA. In contrast, Şeker et al. (2011) conducted dermatophyte isolation from 362 samples obtained from dogs and cats living in Turkey's three largest cities and found microscopic fungi in 52 samples (14.4\%), while positive culture was noted for 70 samples (19.3\%).

In our study, more than one fungal agent was isolated from nine samples, which is in line with the results $(10.6 \%)$ reported by Gülmez et al. (2021). In addition, at least one bacterium was isolated from $14(27.4 \%)$ of 51 samples from which fungi were isolated, as shown in Table 1. As studies as a part of which fungal and bacterial isolation is performed jointly are rare, limited evidence is available to inform clinical treatment. Thus, in most cases, bacterial infections are given a priority and are treated with antibiotics, which would increase the severity of already existing fungal infections.
In their study conducted in Turkey, Yapicier et al. (2017) reported that $56(54.9 \%)$ of 102 samples from cats and dogs with suspected dermatophytosis were found positive for Trichophyton spp. and Microsporum spp. Thus, they emphasized the importance of laboratory diagnosis in suspicious cases and called for animal owners and/or physicians to be more careful about contamination. More recently, Selvi et al. (2019) performed dermatophyte isolation on 60 cats and 60 dogs living in Ankara that did not show clinical symptoms and isolated Microsporum spp. and Trichophyton spp. from $16 \%$ and $10.8 \%$ of the samples. Their findings confirm that zoonotic dermatophytes are common even in animals without clinical symptoms. Similarly, Kaplan et al. (2020) studied the blood taken from four cattle herds with history of previous disease and made the serological diagnosis of Trichophyton ELISA method in $80.3 \%$ of 360 serum samples.

\section{CONCLUSION}

Given that the majority of human infections are caused by zoonotic agents, the data obtained from human and animal laboratories should be evaluated jointly. Although fungal infections are rarely studied, they are becoming more prevalent due to the increased human lifespan, greater success rate of cancer treatments, increased pet ownership, etc., as well as greater reliance on antibiotics. As a part of the present study, animal samples with suspected fungal infection were examined for the presence of both bacteria and fungi. The findings revealed that animals may easily transmit fungal infections to humans, indicating that additional studies should be carried out on fungal infections in both animals and humans in order to establish epidemiological connections.

\section{REFERENCES}

Avsever, M.L., Polat, S.H., Çamkerten, İ., Aksoy, A. (2017). First isolation of Alternia alternata from a dog in Turkey. Journal of Ankara University Veterinary Faculty. 64: 137-139.

Boynukara, B., Gülhan, T., Kurç, M.A. (2019). Komplike mantar enfeksiyonu: muhabbet kuşu. Doğanın sesi. 4: 24-32.

Cafarchia, C., Romito, D., Sasanelli, M., Lia, R., Capelli, G., Otranto, D. (2004). The epidemiology of canine and feline dermatophytoses in southern Italy. Mycoses. 47: 508-513.

Cleaveland, S., Laurenson, M.K., Taylor, L.H. (2001). Diseases of humans and their domestic mammals: pathogen characteristics, host range and the risk of emergence. Philosophical Transactions of the Royal Society B. 356: 991-999.

CLSI. (2012). CLSI Document M54-A. Principles and procedures for detection of fungi in clinical specimens-direct examination and culture, Approved Guideline. $1^{\text {st }}$ edition. Clinical and Laboratory Standarts Institute, Wayne, PA.

Demir, F., Kuştimur, S. (2014). Trichosporon spp. suplarında bazı virulans faktörlerin araptırılması. Microbiology Bulletin. 48: 628-638.

Diler, F.B. (2019). Bursa'da tüketime sunulan çiğ ve pastörize süt örneklerinde alfatoksin $M_{1}$ kontaminasyonunun değerlendirilmesi. Bursa Uludağ Üniversitesi Sağlık Bilimleri Enstitüsü Besin Hijyeni ve Teknolojisi ABD, Yüksek Lisans Tezi. 
Ditrich, O., Rosicky, B., Otcenasek, M. (1990). Urban cycles of zoonotic mycoses. Epidemiology Microbiology Immunology. 39: 335-46.

Gerçeker, B., Ertam, İ., Aytimur, D. (2004). Olgu sunumu: Kediden bulaşan bir tinea corporis olgusu. Sürekli tıp eğitimi dergisi. 13: 392-393.

Gülmez, D., Sığ, A.K., Akar, N., Duyan, S., Akdağlı, S.A. (2021). Enfeksiyon etkeni mantarların zamana göre sıklık ve tür dağılımlarındaki değipimler: 12 yıllık (2008-2019) mikoloji laboratuvarý verileri ne söylüyor ?. Microbiology Bulletin. 55: 53-66.

Gürcan, Ş, Tikveşli, M., Eskiocak, M., Kılıç, H., Otkun, M. (2008). Dermatofitozlarda etkenlerin ve risk faktörlerinin araştırılması: Hastane bazlı bir çalıpma. Microbiology Bulletin. 42: 95-102.

Haggag, Y.N., Samaha, H.A., Nossair, M.A., Mohammed AERMH. (2017). Alexandria Journal of Veterinary Sciences. 53: 64-71.

Hailu, T. (2018). Fungal zoonotic diseases in HIV patients. Jounal of Microbiology and Pathology. 2: 1-7.

Jose, L.B., Marta, E.G. (2010). Animal as reservuar of fungal diseases (zoonoses?), chapter 3. In: Ahmad I, Owais M, Shahid M, Aqil F, Combating Fungal Infections Springer, Germany.

Kaplan, H., Keskin, O. (2020). Siğırlarda Trichophytosis'in tephisinde ELISA'nın kullanılabilirliğinin araptırılması. Etlik Veteriner Mikrobiyoloji Dergisi. 31: 177-183.

Kırdar, S.S. Süt ve ürünlerinde mikotoksinler. Türkiye 9. Gıda kongresi, 24-26 may1s (2006), Bolu. Congres book, s: 307-310.
Mantovani, A., Monganti, L. (1977). Dermatophytozoonoses in İtaly. Veterinary Science Communication. 1: 171-77.

Mısır, G.A., Kendir, C., Güldal, A.D. (2019). Managing zoonotic tinea corporis in primary care: a case report. Turkish Journal of Family Medicine and Primary Care Electronic Journal. 13: 95-99.

Murmu, S., Debnath, C., Pramanik, A.K., Mitra, T., Jana, S., Banerjee, S., Isore, D.P., Batabyal, K. (2017). Characterization and antifungal susceptibility pattern of dermatophtes isolated from dogs, cats and pet owners in and around Kolkata, India. Indian Journal of Animal Research. 51: 336-339.

Quinn, P.J., Carter, M.E., Markey, B. (1999). Section: 2 Bacteriology. In: Clinical Veterinary Microbiology. Harcourt Publishers Limited. 1999, pp. 118-254.

Selvi, B.İ., Yıldırım, M. (2019). Ankara ilindeki kedi ve köpeklerden dermatofitlerin izolasyonu. Eurasian Journal of Veterinary Science. 35: 170-174.

Şeker, E., Doğan, N. (2011). Isolation of dermatophytes from dogs and cats with suspected dermatophytosis in western Turkey. Preventive Veterinary Medicine. 98: 46-51.

Thrusfield, M. (1986). Data bases in epidemiology. Equine Veterinary Journal. 18: 425-431.

Yahyaraeyat, R., Shokri, H., Khosravi, A.R., Soltani, M., Erfanmanesh, A., Nikaein D. (2009). Occurence of animals dermatophytosis in Tehran, Iran. World Journal of Zoology. 4: 200-204.

Yapıcıer, Ö.Ş., Şabanoğlu, E., Öztürk, D., Pehlivanoğlu, F., Kaya, M., Türütoğlu, H. (2017). Kedi ve köpeklerden dermatofitlerin izolasyonu. Mehmet Akif Ersoy Üniversitesi Veteriner Fakültesi Dergisi. 2: 125-130. 